\title{
Effect of grazing on composition, fatty acid profile and nutritional indices of the goat milk and cheese
}

\author{
Á. Bodnár1 , I. Egerszegi ${ }^{1}$, J. Kuchtik ${ }^{3}$, K. Penksza ${ }^{2}$, P. Póti ${ }^{1}$ and F. Pajor ${ }^{1,4}$ \\ Hungarian University of Agriculture and Environmental Sciences, Páter K. u. 1, H-2100, Gödöllö, Hungary \\ ${ }^{1}$ Institute of Animal Sciences, ${ }^{2}$ Institute of Crop Production \\ ${ }^{3}$ Mendel University in Brno, Faculty of AgriSciences, Zemědělská 1665/1, CZ-61300 Brno, Czech Republic
}

KEY WORDS: fatty acids, goats, natural pastures, nutritive value, rumenic acid, somatic cell count

Received: 20 August 2021

Revised: 11 November 2021

Accepted: 13 December 2021

${ }^{4}$ Corresponding author:

e-mail: pajor.ferenc@uni-mate.hu

\begin{abstract}
Twenty lactating Hungarian native goats were randomly divided into two groups to evaluate the effect of extensive grazing on the somatic cell counts (SCC), composition and fatty acid profile of milk and semi-hard cheese. The following important nutritional indices of goat milk and cheese fat were calculated: atherogenic index (Al), health-promoting index (HPI), hypercholesterolemic saturated fatty acids (HFA), hypocholesterolemic/hypercholesterolemic ratio $(H / H)$, linoleic acid/a-linolenic acid ratio (LA/ALA) and thrombogenicity in$\operatorname{dex}(\mathrm{TI})$. The experimental period lasted for 38 days, encompassing the first four weeks as the period of adaptation to the natural pasture and the last ten days as the experimental period. The extensive grazing resulted in significantly higher concentrations of rumenic acid and lower $n-6 / n-3$ ratio in milk $(0.49$ vs $0.67 \%$, $P<0.01$; 3.97 vs $1.49, P<0.001)$ and in cheese (0.44 vs $0.63 \%, P<0.001$; 3.96 vs $1.54, P<0.001)$. The extensive grazing significantly decreased the Al, HFA and LA/ALA, but on the other hand, increased the HPI and $\mathrm{H} / \mathrm{H}$ indices in goat milk and cheese, respectively. The study results suggest that consumers have greater nutraceutical benefits from consuming milk and cheese from goats kept on natural pasture.
\end{abstract}

\section{Introduction}

The global goat milk production was approximately $19.9 \mathrm{mln}$ t in 2019 and relatively continuously has been increasing during the last decades (FAO, 2021). Goat milk production has been growing, but the quantity of different types of goat milk products (typically cheese and yoghurt) has been also increasing year by year. In recent years, goat cheeses have gained increased popularity among consumers due to their nutritional value and health advantages. Small-scale farmers generally produce goat cheeses. This way, cheeses and other goat milk-based products have played an important role in the economic viability of farmers in the world. It is also neces- sary to add that goat cheeses are traditionally one of the crucial goat milk products produced, traded and consumed in large amounts in the world.

Goat breeding and milk production are generally based on natural pastures in rural areas. After forests, grasslands and natural pastures are the most important ecosystems in the world because approximately $37 \%$ of the Earth's terrestrial land surface (more than $50 \mathrm{mln} \mathrm{km}^{2}$, excluding Greenland and Antarctica) is covered by grasslands and natural pastures (O’Mara, 2012). Natural pastures are an essential resource for grazing-based animal production worldwide. In addition, sustainable small ruminant species (such as goat) breeding and keeping play an important role in the economy of marginal 
areas (Colonna et al., 2020). Nevertheless, pasture is one of the most natural feeding sources for animals. It is well-known that the crude fat content in the dry matter of the grass is relatively low; its typical value ranges from 2 to $3 \%$. In contrast, the grass crude fat is rich in $\alpha$-linolenic acid (n-3) (Cabiddu et al., 2005). Feeding green forages to dairy animals increased the concentrations of long-chain fatty acids, such as $\alpha$-linolenic acid (ALA, C18:3) and reduced linoleic acid (LA, C18:2) content and n-6/n-3 ratio in milk and cheese (Pajor et al., 2009, 2012). The high ratio of $n-6 / n-3$ fatty acids is a risk factor in coronary heart disease. The recommended value for the $n-6 / n-3$ ratio is less than 4:1 (Simopoulos, 2016). The milk and cheese fat contain some atherogenic fatty acids, which are harmful to human health. It is well documented that the lauric acid (C12:0), myristic acid (C14:0) and palmitic acid (C16:0) increase the serum low-density lipoprotein cholesterol (LDL-C) level (Ulbricht and Southgate, 1991). In contrast, several fatty acids have a positive effect on human health, such as butyric acid, oleic acid, vaccenic acid, rumenic acid, eicosapentaenoic acid (EPA) and docosahexaenoic acid (DHA) (Santin Junior et al., 2019). Milk fat is evaluated by different nutritional indices, which are based on harmful and advantageous fatty acids. In contrast, to the best of our knowledge, the most important nutritional indices of goat milk and cheese fat [atherogenic index (AI), health-promoting index (HPI), hypercholesterolemic saturated fatty acids (HFA), hypocholesterolemic/hypercholesterolemic ratio $(\mathrm{H} / \mathrm{H})$, linoleic acid/ $\alpha$-linolenic acid ratio (LA/ALA) and thrombogenicity index (TI)] were not evaluated comprehensively in earlier reports in terms of grazing.

The fatty acid profile of the fat is important for the nutritional value of dairy products. In addition, in assessing the nutritional value of milk and cheese, fatty acid-based nutritional indices are increasingly appreciated, which can more reliably measure dietary potential than just the polyunsaturated fatty acid (PUFA)/saturated fatty acid (SFA) ratio (Ulbricht and Southgate, 1991). These selected nutritional indices may help researchers to evaluate the nutritional value of goat milk and cheese fatty acids and to search more easily for their potential usage in human disease prevention. So, we hypothesized that the nutritional value of goat milk and cheese would increase when animals are kept on pasture, moreover, we examined numerous fatty acid-based nutritional indices with potentially better informative value than fatty acid profile alone in the case of milk and cheese evaluation.
Therefore, the aim of this study was to examine the effect of the grazing on the composition (fat and protein contents) and fatty acid profile of the goat milk and cheese, with particular emphasis on beneficial fatty acids and nutritional indices.

\section{Material and methods}

\section{Experimental design}

The experimental procedures and animal care conditions were in compliance with the European guidelines for the care and use of animals in research (Directive 2010/63/EU). With regard to this study, no special permission was needed. The study was carried out in a dairy goat farm situated in Pest County (Hungary). All goats in the present study were balanced for parity and kidding time (beginning of March). The weaning of kids was carried out at the age of 8 weeks. After weaning, all goats were milked twice a day at $06: 00$ and 18:00 by a milking machine. During the first twenty days, all animals were kept confined in the barn together. After that, twenty multiparous Hungarian native goats (21 days in milk) were randomly divided into two groups, 10 animals in each. Control goats were kept indoors and were fed daily $1.5 \mathrm{~kg}$ alfalfa hay and $600 \mathrm{~g}$ commercial concentrate $(17 \%$ crude protein; $7.77 \mathrm{MJ} / \mathrm{kg}$ net energy of lactation $\left(\mathrm{NE}_{1}\right)$ ), while the experimental animals between morning and evening milking were continuously grazing on the natural pasture and overnight they were in the stable. Experimental goats received the same amount and composition of concentrate. The concentrate was individually offered to all animals twice a day in equal amounts during milking (at 06:00 and 18:00). There were no refusals of the concentrate, moreover, there was no ration offered during night rest in the stable.

Utilization of natural pasture was extensive, no artificial fertilizers to pastures were applied to increase the production; stocking density was less than 0.5 animal unit (AU)/ha, to avoid over-grazing of the grassland. The annual grass yield (green) was 1.4 t/ha green yield. The main species were Festuca pseudovina, Cynodon dactylon, and the main legume was Lotus corniculatus.

Before the beginning of the experiment, the green yield of the pasture was estimated by the clipping method using a $2-\mathrm{m}^{2}$ frame. Five random samples were taken ( $3 \mathrm{~cm}$ above the ground) from each site. After grazing, turf residuals were cut, weighted and yields were calculated as before. 
Table 1. Chemical composition and fatty acid profile of forage

\begin{tabular}{lcc}
\hline Indices & Control diet & Experimental diet \\
\hline Ingredients, \% & & \\
alfalfa hay & 71.4 & \multicolumn{1}{l}{} \\
concentrate & 28.6 & 26.2 \\
$\quad$ pasture & - & 73.8 \\
Chemical composition & & \\
dry matter (DM), g/kg forage & 900.0 & 368.7 \\
crude protein, g/kg DM & 198.00 & 162.45 \\
crude fat, g/kg DM & 23.14 & 36.48 \\
crude fibre, g/kg DM & 201.86 & 207.11 \\
crude ash, g/kg DM & 73.00 & 75.15 \\
NE, MJ/kg DM & 6.44 & 6.19 \\
DM intake, kg/day & 1.89 & 1.97 \\
crude protein intake, g & 374.22 & 320.51 \\
NE, intake, MJ & 12.17 & 12.21 \\
Main fatty acids, \% of total fatty acids & \\
C12:0, \% & 0.21 & 0.26 \\
C14:0, \% & 0.63 & 0.55 \\
C16:0, \% & 13.15 & 11.45 \\
C18:0, \% & 2.72 & 1.94 \\
C18:1n-9, \% & 23.82 & 22.18 \\
C18:2n-6, \% & 36.37 & 25.72 \\
C18:3n-3, \% & 19.19 & 31.41 \\
LA/ALA & 1.90 & 0.82 \\
\hline
\end{tabular}

$\mathrm{NE}_{\text {- }}$ - net energy of lactation; LA/ALA - linoleic acid to a-linolenic acid ratio protein intake was slightly different. The energy and protein requirements of goats were adjusted to the recommendations of the National Research Council (NRC, 2007). The chemical composition and fatty acid profile of the diets are presented in Table 1.

The experimental period lasted for 38 days, encompassing the first four weeks as the period of adaptation to the diet and the last 10 days as the testing period. Before the adaption period, at day 0 (pre-treatment day; 20 days in milk), individual milk samples were collected from all goats at morning and evening milkings. After that, during the testing period, bulk milk samples were taken each day from both groups at morning and evening milkings. In addition, cheese samples were prepared from bulk milk every other day five times independently during the experimental period from both groups. The bulk with morning milk was combined with the previous evening milk stored at $4{ }^{\circ} \mathrm{C}$. On each cheese processing day, goat semi-hard cheeses $(1 \mathrm{~kg})$ were made from 101 of milk in parallel in 2 vats. The cheese samples were collected after the 4-week-ripening period, and samples were frozen and stored at $-20{ }^{\circ} \mathrm{C}$ until further analysis. The description of cheese processing is shown in Table 2.

Table 2. Description of experimental cheese processing

\begin{tabular}{|c|c|c|c|}
\hline No. & Technological steps & Circumstances & Duration \\
\hline 1. & Raw milk heating & Temperature: up to $35^{\circ} \mathrm{C}$ & $15 \mathrm{~min}$ \\
\hline 2. & Addition of commercial bacterial culture and rennet & $\begin{array}{l}\text { CHN } 11 \text { (mesophilic aromatic culture) and Chy-Max commercial } \\
\text { rennet (fermentation-produced chymosin) }\end{array}$ & $5 \min$ \\
\hline 3. & Coagulation & & $60 \min$ \\
\hline 4. & Formation of cheeses and moulding blocks & Approx. $1500 \mathrm{~g}$ of each & $10 \mathrm{~min}$ \\
\hline 5. & Post heating & Temperature: up to $38^{\circ} \mathrm{C}$ & $20 \min$ \\
\hline 6. & Scooping and draining & Wheat size & $15 \mathrm{~min}$ \\
\hline 7. & Pressing & $\begin{array}{l}\text { Initial: } 5 \mathrm{~kg} / \mathrm{kg} \text { cheese } \\
\text { Final: } 15 \mathrm{~kg} / \mathrm{kg} \text { cheese }\end{array}$ & $12 \mathrm{~h}$ \\
\hline 8. & Salt bath & $\begin{array}{l}\text { Concentration: } 18 \% \\
\text { Temperature: } 13^{\circ} \mathrm{C}\end{array}$ & $36-48 \mathrm{~h}$ \\
\hline 9. & Ripening & $\begin{array}{l}\text { Temperature: } 17-18^{\circ} \mathrm{C} \\
\text { Relative humidity: } 85 \%\end{array}$ & $\begin{array}{l}4 \text { weeks on oak } \\
\text { board }\end{array}$ \\
\hline
\end{tabular}

Consumed turf yield was calculated by the difference between the pre- and post-grazing grass yield per $\mathrm{m}^{2}$. Hay samples $(n=3)$ were collected before the start of the trial and feeding to the animals.

The mean annual temperature was $12.3^{\circ} \mathrm{C}$, and the total precipitation was $580 \mathrm{~mm}$ in the pasture area. A commercial trace-mineralized salt blocks and drinking water were provided ad libitum to all goats. The energy intake of the control and the experimental diet was balanced, while the crude

\section{Chemical analysis}

The forage samples were analysed for dry matter, crude protein, crude fat, crude fibre and crude ash according to the procedure of the Hungarian Feed Codex (HunMethods of determination of $\mathrm{x}$, 2003).

Methods of determination of dry matter, fat and protein content of cheese samples are described in the Hungarian Standards (Hungarian Standard, 1978, 1980 and 2002). 
Before laboratory examination, morning and evening daily milk samples were collected for analysis. Fat, protein, lactose and total solids contents of milk were determined using a LactoScope ${ }^{\mathrm{TM}}$ infrared spectrophotometer device (Delta Instruments Ltd., Drachten, Netherlands). The somatic cell count (SCC) was analysed using a Bentley FCM apparatus (Livestock Performance Testing Ltd., Gödöllő, Hungary).

The concentrations of individual fatty acids in each milk and cheese sample were determined by a gas chromatography described by Pajor et al. (2019). Briefly, after the lipid extraction and esterification, methyl esters of fatty acids were determined with use of gas chromatographer (GC 2010, Shimadzu, Kyoto, Japan) with a flame ionization detector (FID) and column (CP-SIL-88, $100 \mathrm{~m} \times 0.25 \mathrm{~mm} \times 0.2 \mu \mathrm{m}$, Agilent Technologies, Santa Clara, CA, USA). The fatty acid methyl esters (including $t 10 c 12$ and $c 9 t 11$ CLA isomers) peaks were identified based on the retention times of standard methyl esters of individual fatty acids (Mixture Me 100, Larodan Fine Chemicals AB, Limhamn, Sweden) as described by Szabó et al. (2007). The results were presented as $\mathrm{g} / 100 \mathrm{~g}$ of total fatty acids. The following fatty acid combinations were formed: SFA, monounsaturated fatty acids (MUFA), PUFA, total n-6 and n-3 fatty acids and n- $6 / \mathrm{n}-3$ ratio.

Moreover, following nutritional indices were calculated:

(1) atherogenic index (AI) according to Sinanoglou et al. (2015):

$$
\begin{gathered}
{[\mathrm{C} 12: 0+(4 \times \mathrm{C} 14: 0)+\mathrm{C} 16: 0] / \text { Lunsaturated }} \\
\text { fatty acid (UFA) }
\end{gathered}
$$

(2) health-promoting index (HPI) according to Giorgio et al. (2019):

$$
\Sigma \mathrm{UFA} /[\mathrm{C} 12: 0+(4 \times \mathrm{C} 14: 0)+\mathrm{C} 16: 0]
$$

(3) hypercholesterolemic saturated fatty acids (HFA) according to Barłowska et al. (2018):

$$
\mathrm{C} 12: 0+\mathrm{C} 14: 0+\mathrm{C} 16: 0
$$

(4) hypocholesterolemic/hypercholesterolemic ratio (H/H) according to Sinanoglou et al. (2015): (cis-C18:1 + sPUFA) / (C12:0 + C14:0 + C16:0);

(5) linoleic acid $/ \alpha$-linolenic acid ratio according to Mierliță (2018):

$$
\text { LA/ALA; }
$$

(6) thrombogenicity index (TI) according to Sinanoglou et al. (2015):

$$
\begin{gathered}
(\mathrm{C} 14: 0+\mathrm{C} 16: 0+\mathrm{C} 18: 0) /[(0.5 \times \Sigma \text { MUFA })+ \\
(0.5 \times \Sigma \mathrm{n}-6 \text { PUFA })+(3 \times \Sigma \mathrm{n}-3 \text { PUFA })+ \\
(\mathrm{n}-3 / \mathrm{n}-6)]
\end{gathered}
$$

\section{Statistical analysis}

The SCC values were transformed into logarithmic form to normalize their frequency distribution before performing statistical analysis. The SPSS 25.0 software package (IBM Corporation, Armonk, NY, USA) processed statistical analysis. Statistical analysis was carried out to determine the effect of treatments (fixed effect) on milk and cheese fatty acid content, moreover the effect of type of products (fatty acid profile and nutritional indices between all milk and all cheese samples comparison) on fatty acid content as dependent variables was analysed. Data were presented as mean \pm standard error of the mean (SEM). The significance of differences was assessed by t-test in the case of normal distribution (ShapiroWilk's test). Since data were not normally distributed, variables were subjected to the Mann-Whitney U test.

\section{Results}

Before treatment, there were no significant differences between the two groups in the case of milk composition and SSCs. However, the grazing significantly $(P<0.05)$ affected contents of dry matter (DM) and protein $(\mathrm{P})$ and the $\log \mathrm{SCC}$ with higher values of DM and $\mathrm{P}$ and lower $\log \mathrm{SCC}$ in the experimental group (Table 3 ).

The grazing had a significant effect $(P<0.05)$ on the contents of DM and $\mathrm{P}$ in cheese increasing both these values. On the other hand, the fat (F) content in cheese did not differ significantly between treatments (Table 4).

Table 3. Effect of grazing on the chemical composition of goat milk, mean \pm SEM

\begin{tabular}{lrrrl}
\hline Indices, $\mathrm{g} / 100 \mathrm{~g}$ & $\begin{array}{l}\text { Control } \\
\text { diet, } \\
\mathrm{n}=10^{1}\end{array}$ & $\begin{array}{l}\text { Experimental } \\
\text { diet, } \\
\mathrm{n}=10\end{array}$ & SEM & $P$-value \\
\hline Pre-treatment & & & & \\
$\quad$ fat & 3.58 & 3.51 & 0.037 & N.S. \\
$\quad$ protein & 3.17 & 3.06 & 0.047 & N.S. \\
$\quad$ lactose & 4.62 & 4.64 & 0.027 & N.S. \\
$\quad$ dry matter & 12.07 & 11.92 & 0.059 & N.S. \\
$\quad$ SCC, log cells/ml & 5.98 & 5.93 & 0.04 & N.S. \\
Treatment & & & & \\
$\quad$ fat & 3.50 & 3.46 & 0.051 & N.S. \\
$\quad$ protein & 2.92 & 3.24 & 0.041 & 0.05 \\
$\quad$ lactose & 4.70 & 4.72 & 0.013 & N.S. \\
dry matter & 11.81 & 12.12 & 0.071 & 0.05 \\
SCC, log cells $/ \mathrm{ml}$ & 6.01 & 5.84 & 0.035 & 0.05 \\
\hline
\end{tabular}

1 at pre-treatment: $n=10$ individual milk samples per group, at treatment: $n=10$ bulk samples per group; SEM - standard error of the mean; SCC - somatic cell count; N.S. - not significant 
Table 4. Effect of grazing on the chemical composition of goat cheese, mean \pm SEM

\begin{tabular}{lllll}
\hline Indices, g/100 g & $\begin{array}{l}\text { Control } \\
\text { diet, } \\
\mathrm{n}=5\end{array}$ & $\begin{array}{l}\text { Experimental } \\
\text { diet, } \\
\mathrm{n}=5\end{array}$ & SEM & $P$-value \\
\hline Dry matter (DM) & 45.34 & 47.64 & 0.582 & 0.05 \\
Fat & 19.60 & 20.00 & 0.250 & N.S. \\
Fat in DM & 43.24 & 41.97 & 0.357 & N.S. \\
Protein & 20.80 & 22.60 & 0.396 & 0.05 \\
\hline
\end{tabular}

SEM - standard error of the mean; N.S. - not significant

Grazing increased the concentrations of butyric $(\mathrm{C} 4: 0)$, caproic $(\mathrm{C} 6: 0)$, caprylic $(\mathrm{C} 8: 0)$, stearic (C18:0), oleic (c9C18:1), vaccenic (t11C18:1), linolenic (C18:3), MUFA, total n-3 PUFA and rumenic $(c 9 t 11 \mathrm{C} 18: 2)$ acids. However, on the other hand, the grazing significantly decreased the concentrations of capric (C10:0), lauric (C12:0), myristic (C14:0), myristoleic (C14:1), palmitic (C16:0), palmitoleic (C16:1), linoleic (C18:2), oddchain fatty acids (OCFA), medium-chain fatty acids (MCFA), SFA, PUFA, total n-6 PUFA and n-6/n-3 ratio in goat milk and cheese. The fatty acid profile did not differ between milk and cheese samples. The profile of fatty acid in milk and cheese samples is presented in Table 5.

The nutritional indices of goat milk and cheese samples are presented in Table 6 . The experimental treatment had a significant influence on most of the nutritional indices (except for TI). Both in goat milk and cheese, the grazing significantly $(P<0.001)$ decreased AI, HFA and LA/ALA ratio but increased $(P<0.001)$ the HPI and $\mathrm{H} / \mathrm{H}$ ratio. Moreover, the nutritional indices did not differ between milk and cheese samples.

Table 5. Effect of grazing on selected fatty acids of goat milk and cheese (mean $\pm \mathrm{SEM}$ ), $\mathrm{g} / 100 \mathrm{~g}$ of total fatty acids

\begin{tabular}{|c|c|c|c|c|c|c|c|c|c|}
\hline \multirow[b]{2}{*}{ Fatty acids } & \multicolumn{4}{|c|}{ Milk, $n=10$} & \multicolumn{4}{|c|}{ Cheese, $n=5$} & \multirow[b]{2}{*}{$P$-value MC } \\
\hline & $\begin{array}{l}\text { control } \\
\text { diet }\end{array}$ & $\begin{array}{l}\text { experimental } \\
\text { diet }\end{array}$ & SEM & $P$-value & $\begin{array}{l}\text { control } \\
\text { diet }\end{array}$ & $\begin{array}{l}\text { experimental } \\
\text { diet }\end{array}$ & SEM & $P$-value & \\
\hline Butyric acid & 1.74 & 2.70 & 0.164 & $* * *$ & 1.87 & 2.76 & 0.181 & $* * *$ & N.S. \\
\hline Caproic acid & 2.34 & 3.02 & 0.119 & $* * *$ & 2.38 & 3.22 & 0.162 & $* * *$ & N.S. \\
\hline Caprylic acid & 2.31 & 2.69 & 0.076 & $* *$ & 2.33 & 2.74 & 0.073 & $* * *$ & N.S. \\
\hline Capric acid & 9.04 & 8.82 & 0.051 & * & 9.20 & 8.80 & 0.080 & ** & N.S. \\
\hline Lauric acid & 4.54 & 3.26 & 0.216 & $* * *$ & 4.54 & 3.30 & 0.210 & $* * *$ & N.S. \\
\hline Myristic acid & 11.16 & 9.12 & 0.348 & $* \star *$ & 11.64 & 9.51 & 0.363 & $* *$ & N.S. \\
\hline Myristoleic acid & 0.23 & 0.09 & 0.025 & $* * *$ & 0.22 & 0.08 & 0.023 & $* * *$ & N.S. \\
\hline Palmitic acid & 32.82 & 27.62 & 0.876 & $* * *$ & 33.12 & 28.30 & 0.832 & $* * *$ & N.S. \\
\hline Palmitoleic acid & 0.85 & 0.57 & 0.048 & $* * *$ & 0.79 & 0.54 & 0.044 & $* * *$ & N.S. \\
\hline Stearic acid & 5.87 & 11.68 & 0.973 & $* * *$ & 5.65 & 11.45 & 0.966 & $* * *$ & N.S. \\
\hline Oleic acid & 20.19 & 22.01 & 0.339 & $* * *$ & 20.04 & 22.38 & 0.423 & $* * *$ & N.S. \\
\hline Vaccenic acid & 0.89 & 1.57 & 0.114 & $\star \star \star *$ & 0.81 & 1.49 & 0.110 & $* * *$ & N.S. \\
\hline Linoleic acid & 2.68 & 1.72 & 0.161 & $\star * *$ & 2.60 & 1.71 & 0.152 & $* * *$ & N.S. \\
\hline t10c12CLA & 0.10 & 0.11 & 0.006 & N.S. & 0.13 & 0.12 & 0.008 & N.S. & N.S. \\
\hline $\begin{array}{l}\text { c9t11CLA } \\
\text { (rumenic acid) }\end{array}$ & 0.49 & 0.67 & 0.035 & $* *$ & 0.44 & 0.63 & 0.031 & $* * *$ & N.S. \\
\hline a-linolenic acid & 0.43 & 1.10 & 0.113 & $* * *$ & 0.41 & 1.08 & 0.113 & $* * *$ & N.S. \\
\hline OCFA & 2.33 & 1.90 & 0.052 & $* * *$ & 2.30 & 1.87 & 0.074 & $* \star *$ & N.S. \\
\hline MCFA & 15.89 & 14.76 & 0.200 & $* * *$ & 15.78 & 17.51 & 0.354 & $* * *$ & N.S. \\
\hline SFA & 72.63 & 71.32 & 0.294 & * & 73.53 & 72.46 & 0.248 & * & N.S. \\
\hline MUFA & 22.20 & 24.27 & 0.378 & $* * *$ & 21.89 & 24.52 & 0.463 & $* * *$ & N.S. \\
\hline PUFA & 4.08 & 3.81 & 0.054 & $* *$ & 3.91 & 3.71 & 0.265 & $* *$ & N.S. \\
\hline PUFA n-6 & 2.86 & 1.88 & 0.165 & $* * *$ & 2.77 & 1.86 & 0.157 & $* * *$ & N.S. \\
\hline PUFA n-3 & 0.72 & 1.26 & 0.090 & $\star \star \star *$ & 0.70 & 1.21 & 0.090 & $* \star *$ & N.S. \\
\hline$n-6 / n-3$ & 3.97 & 1.49 & 0.418 & $\star * *$ & 3.96 & 1.54 & 0.434 & $\star \star *$ & N.S. \\
\hline
\end{tabular}

${ }^{*} P<0.05 ;{ }^{* *} P<0.01 ;{ }^{* * *} P<0.001$ - significant differences between control diet and experimental diet; $P$-value MC $-P$-value between milk and cheese; N.S. - not significant; SEM - standard error of the mean; CLA - conjugated linoleic acid, OCFA - odd-chain fatty acids, MCFA - medium chain fatty acids, SFA - saturated fatty acids, MUFA - monounsaturated fatty acids, PUFA - polyunsaturated fatty acids 
Table 6. Effect of grazing on nutritional indices of goat milk and cheese, mean \pm SEM

\begin{tabular}{|c|c|c|c|c|c|c|c|c|c|}
\hline \multirow[b]{2}{*}{ Indices } & \multicolumn{4}{|c|}{ Milk, $n=10$} & \multicolumn{4}{|c|}{ Cheese, $n=5$} & \multirow[b]{2}{*}{$P$-value MC } \\
\hline & $\begin{array}{l}\text { control } \\
\text { diet }\end{array}$ & $\begin{array}{l}\text { experimental } \\
\text { diet }\end{array}$ & SEM & $P$-value & $\begin{array}{l}\text { control } \\
\text { diet }\end{array}$ & $\begin{array}{l}\text { experimental } \\
\text { diet }\end{array}$ & SEM & $P$-value & \\
\hline $\mathrm{Al}$ & 3.12 & 2.40 & 0.122 & 0.001 & 3.26 & 2.47 & 0.138 & 0.001 & N.S. \\
\hline $\mathrm{HPI}$ & 0.32 & 0.42 & 0.016 & 0.001 & 0.31 & 0.41 & 0.017 & 0.001 & N.S. \\
\hline HFA & 48.52 & 40.00 & 1.430 & 0.001 & 49.30 & 41.10 & 1.403 & 0.001 & N.S. \\
\hline$H / H$ & 0.50 & 0.65 & 0.024 & 0.001 & 0.49 & 0.63 & 0.026 & 0.001 & N.S. \\
\hline LA/ALA & 6.33 & 1.56 & 0.801 & 0.001 & 6.34 & 1.58 & 0.812 & 0.001 & N.S. \\
\hline $\mathrm{TI}$ & 2.67 & 2.64 & 0.014 & N.S. & 2.74 & 2.68 & 0.018 & N.S. & N.S. \\
\hline
\end{tabular}

$\mathrm{Al}$ - index of atherogenicity, HPI - health promoting index, HFA - hypercholesterolemic fatty acids $(\mathrm{C} 12: 0+\mathrm{C} 14: 0+\mathrm{C} 16: 0)$, $\mathrm{H} / \mathrm{H}$ - hypocholesterolemic to hypercholesterolemic acids ratio, LA/ALA - linoleic acid to a-linolenic acid ratio, $\mathrm{TI}$ - index of thrombogenicity, N.S. - not significant, SEM - standard error of the mean, $P$-value MC - $P$-value between milk and cheese

\section{Discussion}

In general, in the present study, it was demonstrated that, the basic milk parameters were affected by grazing, while the contents of DM, P and $\log$ SCC in the milk of grazing goats were more favourable than in control ones. These findings suggest that milk from grazing animals should have a higher cheese yield due to its higher protein content, and lower SCCs should favourably affect milk coagulation and the quality of final products.

However, in general, it can be stated that all values of basic milk parameters in both groups in the present study were comparable with the earlier reports (Kuchtík et al., 2015; Pajor et al., 2019). In addition, the $\log \mathrm{SCC}$ values in both groups were also consistent with the results published by Kuchtík et al. (2015).

Concerning the chemical composition of cheese, the obtained results were very similar to the data reported by Pajor et al. (2012). As mentioned above, the $\log$ SCC value was lower in grazed animals than in those fed the control diet. This result may indicate enhanced mammary gland health in goats kept on pasture. In dairy animals, when mastitis occurs, the mammary epithelial cell membranes are significantly damaged; as a result, milk secretion is reduced (Barbano et al., 2006). Gantner and Kompan (2009) reported that high n-3 PUFA intake had a beneficial effect on udder health; the goats fed an ALA-enriched diet (similar to grass fat) produced milk containing lower SCC. Our results may suggest that ALA consumed with grass might have been incorporated into membrane phospholipids in the udder and so might have significantly improved the mammary epithelial cells functionality.

The grazing had a beneficial effect on the concentrations of short-chain fatty acids (butyric, caproic and caprylic acids) in milk and cheese, which were higher in the experimental group in compari- son to the control one. It is well known that SFAs are hydrolysed rapidly and directly absorbed from the intestinal wall to the liver portal vein. Furthermore, Gómez-Cortés et al. (2018) demonstrated that the short- and medium-chain fatty acids are healthpromoting components; these fatty acids can help maintain the balance of the gut microbiota and control human body weight.

In addition, the grazing significantly affected the medium-chain fatty acids concentrations due to the low content of myristie $(\mathrm{C} 14: 0)$ and palmitic (C16:0) acids in the grass. The relatively high concentration of PUFAs in the diet inhibits de novo fatty acid synthesis in the mammary gland (Couvreur et al., 2006; Cosentino et al., 2021). Moreover, the hay-based diet contained elevated concentrations of myristic and palmitic acid. This was confirmed by higher values of myristic and palmitic fatty acids content in milk and cheese of hay-based diet-fed goats.

The PUFA, such as LA and ALA, are partly saturated in the rumen by biohydrogenation. Throughout this process, the vaccenic acid is formed from LA in the rumen in an anaerobic way. Vaccenic acid is later converted to rumenic acid by $\Delta 9$-desaturase in the mammary gland (Kuhnt et al., 2006). The grazing positively affected the concentration of vaccenic and rumenic acids in the milk and cheese samples because these fatty acids concentrations in the experimental milk and cheese were elevated in comparison to the control group. It is well known, that rumenic acid has a beneficial effect on human health - it suppresses carcinogenesis and reduces atherogenesis (Lock et al., 2009; Tarricone et al., 2021). Another conjugated linoleic acid (CLA) isomer, $t 10 c 12 \mathrm{CLA}$, was observed in this study; however, as it was also found by Pajor et al. (2009), similar concentrations in control and experimental milk and cheese were found. 
Because of the biohydrogenation process in the rumen, the stearic acid concentration expressively increased in the experimental milk and cheese in comparison to control samples. The high availability of stearic acid might have been influenced by the oleic acid ( $c 9 \mathrm{C} 18: 1)$ concentration in both milk and cheese which was also higher in experimental milk and cheese samples than in control ones.

Lower values of the odd-chain fatty acids (OCFA) concentrations were detected in the milk and cheese from experimental animals in comparison to milk and cheese from control goats. The OCFA are a good indicator of ruminal fermentation as they are produced by ruminal bacterial populations. Rego et al. (2016) observed a decreased concentration of OCFA in milk fat when dairy animals were fed pasture. In contrast, Rutkowska et al. $(2012,2015)$ found an increase in milk OCFA when cows were kept on pasture.

In our study, the grass fat contained more ALA and less LA than alfalfa hay. Furthermore, the LA/ALA ratio is significantly different in grass and alfalfa hay fat. Due to the different ratios of these fatty acids in feeds, the level of ALA increased, while the level of LA decreased in milk and cheese from experimental group. Nevertheless, ALA is the precursor of EPA (C20:5 n-3) and DHA (C22:6n-3), which are required for many metabolic processes in humans and effectively prevent coronary heart disease (Baker et al., 2016). However, only a relatively small proportion of ALA is metabolized to EPA and even less to DHA (Baker et al., 2016).

In our study, the n-6/n-3 ratio dramatically decreased in the milk and cheese samples of grazing group in comparison to the control ones. This is in concordance with many earlier reports. For example, Pajor et al. (2009) found that the $n-6 / n-3$ ratio in goat milk and cheese considerably decreased when the animals were kept on pasture. Nowadays, the value of the $n-6 / n-3$ ratio is the focus of healthy nutrition. The recommended value of the $n-6 / n-3$ ratio by nutritionists is less than 4 (British Department of Health, 1994). In our study, this value is lower than the threshold limit of 4, which is considered protective against cardiovascular and chronic diseases (Simopoulos, 2016).

The milk and cheese samples fatty acid profiles were similar, all cheese samples preparing technical parameters were the same, and the ripening was relatively short. In addition, cheese fatty acid concentrations are influenced by several other factors, such as bacterial cultures and the ripening process (Białek et al., 2020).
In the present study, grazing has a significant effect on nutritional indices (except for TI). The AI was firstly applied by Ulbricht and Southgate (1991) and is used to characterize the atherogenic potential of fatty acids in foods. In this study, AI was proven to be significantly lower in the milk and cheese from experimental animals in comparison to control ones. Diets with a high AI may be detrimental to health (Pilarczyk et al., 2015). The average AI values (control 3.12, experimental 2.40) in the present trial were in agreement with the previous report of Pittau et al. (2013), in which AI were 2.80 and 2.27, respectively for conventional and organic goat milk; but slightly higher than recommended value (2.0) reported by Ulbricht and Southgate (1991). The HPI was evaluated by Chen et al. (2004), who studied the effect of fatty acid composition on coronary heart disease according to the nutritional value of dietary fat. The goat grazing led to a higher concentration of oleic acid in milk, and in parallel resulted in lower concentrations of lauric, myristic and palmitic acids. Therefore, better HPI was in the experimental milk and cheeses in comparison to control samples. Concentrations of lauric, myristic and palmitic acids, which are the HFAs, were lower in experimental milk and cheese samples than in control ones. These fatty acids are most strongly associated with higher total cholesterol and LDL-C concentrations in blood serum (Ulbricht and Southgate, 1991). In parallel to the HFA, the grazing considerably improved the $\mathrm{H} / \mathrm{H}$ ratio in milk and cheese. The $\mathrm{H} / \mathrm{H}$ ratio is described as the relationship between hypocholesterolemic fatty acids (cis-C18:1 and PUFA) and hypercholesterolemic fatty acids (lauric, myristic and palmitic acids). In our study, the $\mathrm{H} / \mathrm{H}$ ratio was higher in the milk and cheese samples from the experimental group than in the control samples, while the $\mathrm{H} / \mathrm{H}$ ratios in both samples of milk were in line with the results published by Chen and Liu (2020), who summarized the current knowledge about the $\mathrm{H} / \mathrm{H}$ ratio in the milk of ruminants. In the present study, the grazing diet considerably decreased the LA/ALA ratio in milk and cheese due to the high content of ALA in grass fat. The LA/ALA ratio is more important for baby food than adult diet as reported by Chen and Liu (2020). In contrast, there were no significant differences between the control and grazing animals in the case of TI. However, the average values of TI for control and experimental samples in milk (2.67 vs 2.64) and cheese (2.74 vs 2.68) were in line with the results reported in previous studies concerning goat milk (Pittau et al., 2013) and cheese (Paszczyk and Łuczyńska, 2020). 


\section{Conclusions}

Grazing increased the protein and dry matter content in goat milk and cheese, while reducing the somatic cell count in milk. Furthermore, grazing resulted in significantly higher concentrations of shortchain fatty acids, long-chain fatty acids, rumenic acid and n-3 fatty acids, and a lower n- $6 / \mathrm{n}-3$ ratio in milk and cheese samples. Moreover, grazing considerably decreased the concentration of the harmful fatty acids and improved the nutritional value of milk and cheese, which was confirmed by the nutritional indices. The lower atherogenic index, hypercholesterolemic saturated fatty acids and linoleic acid/ $\alpha$-linolenic acid ratio values and higher health-promoting index and hypocholesterolemic/hypercholesterolemic ratio values in the goat milk and cheese are in accordance with the new recommendations for human nutrition. So, it may be suggested that milk and cheese from goats kept on natural pasture might exert a healthpromoting effect decreasing the incidence of coronary heart disease.

\section{Acknowledgements}

This work is supported by the EFOP-3.6.3VEKOP-16-2017-00008 project. The project is cofinanced by the European Union and the European Social Fund. This research was funded by the OTKA H-12423 and VEKOP-2.1.7-15-2016-00642 projects. This research was supported by the Ministry of Innovation and Technology within the framework of the Thematic Excellence Program 2020, Institutional Excellence Sub-Program (TKP2020-IKA-12) in the topic of water-related researches of Hungarian University of Agricultural and Life Sciences. The authors would like to thank the owners of Monor-Vasad Goats Farm for their technical assistance.

\section{Conflict of interest}

The authors declare that there is no conflict of interest.

\section{References}

Baker E.J., Miles E.A., Burdge G.C., Yaqoob P., Calder P.C., 2016. Metabolism and functional effects of plant-derived omega-3 fatty acids in humans. Prog. Lipid. Res. 64, 30-56, https://doi. org/10.1016/j.plipres.2016.07.002

Barbano D.M., Ma Y., Santos M.V., 2006. Influence of raw milk quality on fluid milk shelf life. J. Dairy Sci. 89, Suppl., E15-E19, https://doi.org/10.3168/jds.S0022-0302(06)72360-8
Barłowska J., Pastuszka R., Rysiak A., Król J., Brodziak A., Kędzierska-Matysek M., Wolanciuk A., Litwińczuk Z., 2018. Physicochemical and sensory properties of goat cheeses and their fatty acid profile in relation to the geographic region of production Int. J. Dairy Technol. 71, 699-708, https://doi. org/10.1111/1471-0307.12506

Białek A., Białek M., Lepionka T., Czerwonka M., Czauderna M., 2020. Chemometric analysis of fatty acids profile of ripening chesses. Molecules 25, 1814, https://doi.org/10.3390/molecules 25081814

British Department of Health, 1994. Nutritional aspects of cardiovascular disease. Report of the Cardiovascular Review Group Committee on Medical Aspects of Food Policy. Rep. Health Soc. Subj. (Lond.) 46, 1-186

Cabiddu A., Decandia M., Addis M., Piredda G., Pirisi A., Molle G., 2005. Managing Mediterranean pastures in order to enhance the level of beneficial fatty acids in sheep milk. Small Rumin. Res. 59, 169-180, https://doi.org/10.1016/j.smallrumres.2005.05.005

Chen J., Liu H., 2020. Nutritional indices for assessing fatty acids: a mini-review. Int. J. Mol. Sci. 21, 5695, https://doi. org/10.3390/ijms21165695

Chen S., Bobe G., Zimmerman S., Hammond E.G., Luhman C.M., Boylston T.D., Freeman A.E., Beitz D.C., 2004. Physical and sensory properties of dairy products from cows with various milk fatty acid compositions. J. Agric. Food Chem. 52, 3422-3428, https://doi.org/10.1021/jf035193z

Colonna M.A., Rotondi P., Selvaggi M., Caputi Jambrenghi A., Ragni M., Tarricone S., 2020. Sustainable rearing for kid meat production in Southern Italy marginal areas: a comparison among three genotypes. Sustainability 12,6922 , https://doi. org/10.3390/su12176922

Cosentino C., Colonna M.A., Musto M., Dimotta A., Freschi P., Tarricone S., Ragni M., Paolino R., 2021. Effects of dietary supplementation with extruded linseed and oregano in autochthonous goat breeds on the fatty acid profile of milk and quality of Padraccio cheese. J. Dairy Sci. 104, 1445-1453, http://doi. org/10.3168/jds.2020-18805

Couvreur S., Hurtaud C., Lopez C., Delaby L., Peyraud J.L., 2006. The linear relationship between the proportion of fresh grass in the cow diet, milk fatty acid composition, and butter properties. J. Dairy Sci. 89, 1956-1969, https://doi.org/10.3168/jds. S0022-0302(06)72263-9

FAO (Food and Agriculture Organisation of the United Nation), 2021. FAOSTAT - Statistical Databases. http://www.fao.org/faostat/ en/\#data/QCL [2021-10-30]

Gantner V., Kompan D., 2009. Effect of a-linoleic acid supplementation in goat's diet on milk yield, quality and somatic cell count. Ital. J. Anim. Sci. 8, Suppl. 3, 139-141, https://doi.org/10.4081/ ijas.2009.s3.139

Giorgio D., Di Trana A., Di Napoli M.A., Sepe L., Cecchini S., Rossi R., Claps S., 2019. Comparison of cheeses from goats fed 7 forages based on a new health index. J. Dairy Sci. 102, 6790-6801, https://doi.org/10.3168/jds.2018-15857

Gómez-Cortés P., Juárez M., de la Fuente M.A., 2018. Milk fatty acids and potential health benefits: An updated vision. Trends Food Sci. Technol. 81, 1-9, https://doi.org/10.1016/j. tifs.2018.08.014

Hungarian Feed Codex, 2003. Laboratory methods and operations (in Hungarian). Magyar Közlöny 42, 3388-3436

Hungarian Standard, 1978. Determination of nitrogen content for calculation of the protein content. MSZ 5874-8:1978

Hungarian Standard, 1980. Determination of the dry matter content. MSZ 5874-4:1980 
Hungarian Standard, 2002. Raw fat content determination by diethyl ether extraction. MSZ ISO 1443:2002

Kuchtík J., Králičková S., Zapletal D., Węglarzy K., Šustová K., Skrzyżała I., 2015. Changes in physico-chemical characteristics, somatic cell count and fatty acid profile of Brown Shorthaired goat milk during lactation. Anim. Sci. Pap. Rep. 33, 71-83

Kuhnt K., Kraft J., Moeckel P., Jahreis G., 2006. Trans-11-18:1 is effectively 89 -desaturated compared with trans-12-18:1 in humans. Br. J. Nutr. 95, 752-761, https://doi.org/10.1079/ bjn20051680

Lock A.L., Kraft J., Rice B.H., Bauman D.E., 2009. Biosynthesis and biological activity of rumenic acid: a natural CLA isomer. In: F. Destaillats, J.L. Sébédio, F. Dionisi, J.M. Chardigny (Editors). Trans Fatty Acids in Human Nutrition. Oily Press (UK), pp. 195-230, https://doi.org/10.1533/9780857097873.195

Mierliț̆ D., 2018. Effects of diets containing hemp seeds or hemp cake on fatty acid composition and oxidative stability of sheep milk. S. Afr. J. Anim. Sci. 48, 504-515, https://doi.org/10.4314/sajas.v48i3.11

NRC (National Research Council), 2007. Nutrient Requirements of Small Ruminants: Sheep, Goats, Cervids, and New World Camelids. The National Academies Press. Washington, DC (USA), https://doi.org/10.17226/11654

O'Mara F.P., 2012. The role of grasslands in food security and climate change. Ann. Bot. 110, 1263-1270, https://doi.org/10.1093/ aob/mcs209

Pajor F., Egerszegi I., Steiber O., Bodnár Á., Póti P., 2019. Effect of marine algae supplementation on the fatty acid profile of milk of dairy goats kept indoor and on pasture. J. Anim. Feed Sci. 28, 169-176, https://doi.org/10.22358/jafs/109955/2019

Pajor F., Galló O., Steiber O., Tasi J., Póti P., 2009. The effect of grazing on the composition of conjugated linoleic isomers and other fatty acids of milk and cheese in goats. J. Anim. Feed Sci. 18, 429-439, https://doi.org/10.22358/jafs/66418/2009

Pajor F., Steiber O., Tasi J., 2012. Influence of extensive grazing on cheese composition, yield and fatty acids content of goats. Bulg. J. Agric. Sci. 18, 487-492

Paszczyk B., Łuczyńska J., 2020. The comparison of fatty acid composition and lipid quality indices in hard cow, sheep, and goat cheeses. Foods 9, 1667, https://doi.org/10.3390/ foods 9111667

Pilarczyk R., Wójcik J., Sablik P., Czerniak P., 2015. Fatty acid profile and health lipid indices in the raw milk of Simmental and Holstein-Friesian cows from an organic farm. S. Afr. J. Anim. Sci. 45, 30-38, https://doi.org/10.4314/sajas.v45i1.4
Pittau D., Panzalis R., Spanu C., Scarano C., De Santis E.P.L., 2013. Survey on the fatty acids profile of fluid goat milk. Ital. J. Food Saf. 2(3), e33, https://doi.org/10.4081/ijfs.2013.1537

Rego O.A., Cabrita A.R.J., Rosa H.J.D., Alves S.P., Duarte V., Fonseca A.J.M., Vouzela C.F.M., Pires F.R., Bessa R.J.B., 2016. Changes in milk production and milk fatty acid composition of cows switched from pasture to a total mixed ration diet and back to pasture. Ital. J. Anim. Sci. 15, 76-86, https://doi.org/1 0.1080/1828051X.2016.1141330

Rutkowska J., Adamska A., Bialek M., 2012. Fatty acid profile of the milk of cows reared in the mountain region of Poland. J. Dairy Res. 79, 469-476, https://doi.org/10.1017/ S0022029912000428

Rutkowska J., Bialek M., Adamska A., Zbikowska A., 2015. Differentiation of geographical origin of cream products in Poland according to their fatty acid profile. Food Chem. 178, 26-31, https://doi.org/10.1016/j.foodchem.2015.01.036

Santin Junior I.A., Silva K.C.C., Cucco D.C., 2019. Milk fatty acids profile and the impact on human health. Dairy Vet. Sci. J. 10, 555779, https://doi.org/10.19080/JDVS.2019.10.555779

Simopoulos A.P., 2016. An increase in the omega-6/omega-3 fatty acid ratio increases the risk for obesity. Nutrients 8,128 , https://doi.org/10.3390/nu8030128

Sinanoglou V.J., Koutsouli P., Fotakis C., Sotiropoulou G., Cavouras D., Bizelis I., 2015. Assessment of lactation stage and breed effect on sheep milk fatty acid profile and lipid quality indices. Dairy Sci. Technol. 95, 509-531, https://doi.org/10.1007/ s13594-015-0234-5

Szabó A., Fébel H., Sugár L., Romvári R., 2007. Fatty acid regiodistribution analysis of divergent animal triacylglycerol samples a possible approach for species differentiation. J. Food Lipids 14, 62-77, https://doi.org/10.1111/j.1745-4522.2006.00071.x

Tarricone S., Giannico F., Ragni M., Colonna M.A., Rotondi P., Cosentino C., Seidavi A., Tufarelli V., Laudadio V., 2021. Effects of dietary extruded linseed (Linum usitatissimum L.) and oregano (Origanum vulgare) on growth traits, carcass composition and meat quality of Grigia di Potenza suckling kids. Int. J. Agric. Biol. 25, 1147-1152, https://doi.org/10.17957/ IJAB/15.1775

Ulbricht T.L.V., Southgate D.A.T., 1991. Coronary heart disease: seven dietary factors. Lancet 338, 985-992, https://doi. org/10.1016/0140-6736(91)91846-m 